Review

\title{
Evolutionary Models of the Cenozoic Basins of Central-Western Mediterranean Area: A Review of Methodological Approaches
}

\author{
Francesco Guerrera ${ }^{1}$, Manuel Martín-Martín ${ }^{2}\left(\mathbb{D}\right.$ and Mario Tramontana ${ }^{3, *(D)}$ \\ 1 Ex-Dipartimento di Scienze della Terra, della Vita e dell'Ambiente (DiSTeVA), Università degli Studi di \\ Urbino Carlo Bo, 61029 Urbino, Italy; francesco@guerrera.biz \\ 2 Departamento de Ciencias de la Tierra y Medio Ambiente, University of Alicante, 03690 Alicante, Spain; \\ manuel.martin.m3@gmail.com \\ 3 Dipartimento di Scienze Pure e Applicate (DiSPeA), Università degli Studi di Urbino Carlo Bo, \\ 61029 Urbino, Italy \\ * Correspondence: mario.tramontana@uniurb.it
}

Received: 18 August 2020; Accepted: 8 September 2020; Published: 15 September 2020

\begin{abstract}
In the last 40 years, several models based on very different methodological approaches have been proposed to interpret the complex geodynamic evolution of the central-western Mediterranean area and, in particular, of the Cenozoic basins. The persistence of numerous interpretations and still-open problems resulted in the proliferation of very different models. The reconstructions presented are highly influenced by difficulties often encountered in considering constraints introduced by models built by means of completely different methodological approaches. For example, major difficulties can arise in integrating data from individual classical disciplines (i.e., geology, stratigraphy, geophysics, tectonics, magmatology and plate kinematics) with those resulting from the use of modern technologies (i.e., digital processing, uses of software, field observations using drones, etc.) and generally aimed to support specific topics. These considerations lead researchers to believe that a multidisciplinary approach would always be auspicious for these studies, because a greater control of the reconstruction of geologic and geodynamic events, and, therefore, for resulting models, would be ensured. After some considerations about different types of literature models based on specific investigation methodologies, the updating of a recently presented evolutionary model is proposed by attempting to integrate as much data as possible about the Cenozoic basins of the central-western Mediterranean area.
\end{abstract}

Keywords: Mediterranean area; geodynamic models; methodological approach; geological evolution

\section{Introduction}

Different evolutionary models concerning the evolution of the Cenozoic basins involved in the Maghrebian Chain and its lateral continuations (Betic Cordillera and Apennines) around the central-western Mediterranean area have been proposed in the geological literature.

In this context, the tectono-sedimentary evolution of structural elements as the Betic-Rifian Arc, the Calabria-Peloritani Arc, the North African and Sicilian chains and the lateral extension in the Apennines played a very important role. In particular, the Maghrebian Flysch Basin (MFB) is an important and well-known paleogeographic element along the Maghrebian Chain, which deformed during the neo-Alpine Miocene tectonic evolution and now sandwiched between internal and external zones in all sectors of the chains.

The paleogeography inherited from the Hercynian orogeny on which the Alpine history begins, favored the development of the Miocene Apennine-Maghrebian chains during the neo-alpine stage. The opening of the central-western Mediterranean and associated features (Alboran area, Betic-Rifian 
Arc, Algerian-Provencal Basin, Corsica-Sardinia Block migration, Calabria-Peloritani Arc, Tyrrhenian Sea opening, etc.) are connected to the evolution of this last system. The reconstruction of the complex evolutionary stages of the area still presents many problems that are not yet completely clarified and outdated, resulting in the proliferation of different reconstructions.

In particular, the state-of-the-art knowledge of the central-western peri-Mediterranean Cenozoic basins/chains has not yet reached a level sufficient to significantly reduce the still-persistent differences in models and related problems ([1] and references therein). Based on the collected data, it seems clear that the differences between models result mainly from the different methodological approach followed by the different authors.

An interpretative model usually is useful to unify and better understand a set of data. A good model can represent an excellent working tool for the scientific community if built according to specific scientific criteria of the Earth Sciences. Models are not complete because many details are missing and/or not entirely reliable. However, every effort is still useful to improve knowledge as it leads to a more advanced work tool.

\section{Methodological Approach}

Historically, scientific research methods utilized to elaborate logical reasoning are essentially two. The deductive method, which starts from one or more premises and applying logical reasoning, reaches a conclusion to propose to the scientific community. This approach allows understanding logical truths, with a result always clear (true or false) even if not always evident in a short time. In the case of geological reconstructions, it is impossible to achieve complete and definitive certainties.

On the other hand, the inductive method is the most suitable to be applied in geological research. In this case, the challenge begins with the setting of some empirical premises to be evaluated (or not) through experimental data and that reach uncertain conclusions. The application of this method considers the repeatability of one or more connected phenomena from which an interpretative/cognitive framework can be obtained, which, however, does not assure that the result is right or suitable. If many observations and analytical data are considered the resulting interpretation will probably be more coherent and sustainable. Moreover, a conclusion based on the inductive method would not be of great use when lacking a probabilistic/statistical estimate validating the correctness. The progressive collection of evidence can favor an ever-greater clarity and detail, thus reinforcing the interpretation or obliging the final rejection.

This latter approach is coherent and useful for geologists because limitations (in addition to the intrinsic one of the general geological method) are related to the loss of information caused by erosion of portion of the stratigraphic records and by the obliteration of events due to the superimposition of orogenic phases. Other limitations result from the impossibility of analyzing all the available rocks of the stratigraphic record of basins. Therefore, the geological research can rarely apply in a completely exhaustive way to the inductive method because often it is necessary to change previously assumed opinions based on new data and evidence. In fact, it is common to change one's vision and interpretation and to adjust them considering the continuously emerging new data.

Therefore, every model can be more or less truthful but must be abandoned when exceeded thanks to discoveries and it may be equally important if it has been useful to increase the state of knowledge.

In short, the proposed study aims to show the actual differences still existing between evolutionary models chosen as meaningful and exemplary cases of a certain methodology used. Secondly, an attempt will be made to point out comparatively the reasons for the differences emerging in the different reconstructions.

Finally, we will try to develop considerations about the choice of a geological model that in our opinion can represent better a plausible evolutionary reference framework for the wide chain system surrounding the central-western Mediterranean area. 
This approach does not mean to exclude or diminish the importance of other different models addressed to this topic, but the only aim is to stimulate some reflections about the current knowledge to promote the comparison between different methodologies (classic and modern) used in Earth Sciences.

\section{Geological Models}

The Cenozoic basins incorporated in the peri-Mediterranean chains (Figure 1) experienced a different evolution linked to the development of subduction zones after the Mesozoic and early Cenozoic fragmentation and that changed over time the paleogeography of the area between African and Eurasia plates. In particular, the neo-Alpine orogenic system (Betic, Maghrebian and Apennine chains) consists of three major paleogeographic and paleotectonic zones extending from Iberia-Europe to Africa-Adria plates: (i) Internal zone (well represented in the Betic-Rif Arc, Alboran, Kabylies, Calabria-Peloritani Arc and Apennines), originated for a part of authors from the European margin and for other authors an intermediate and independent microplate located between Europa and Africa; (ii) Intermediate zone (Maghrebian Basin) corresponding to a southern branch of the Tethys (mainly basinal sedimentation on oceanic and continental thinned crust); (iii) External zone belonging to the Adria-Africa margin representing the southern boundary of the Maghrebian Tethys.

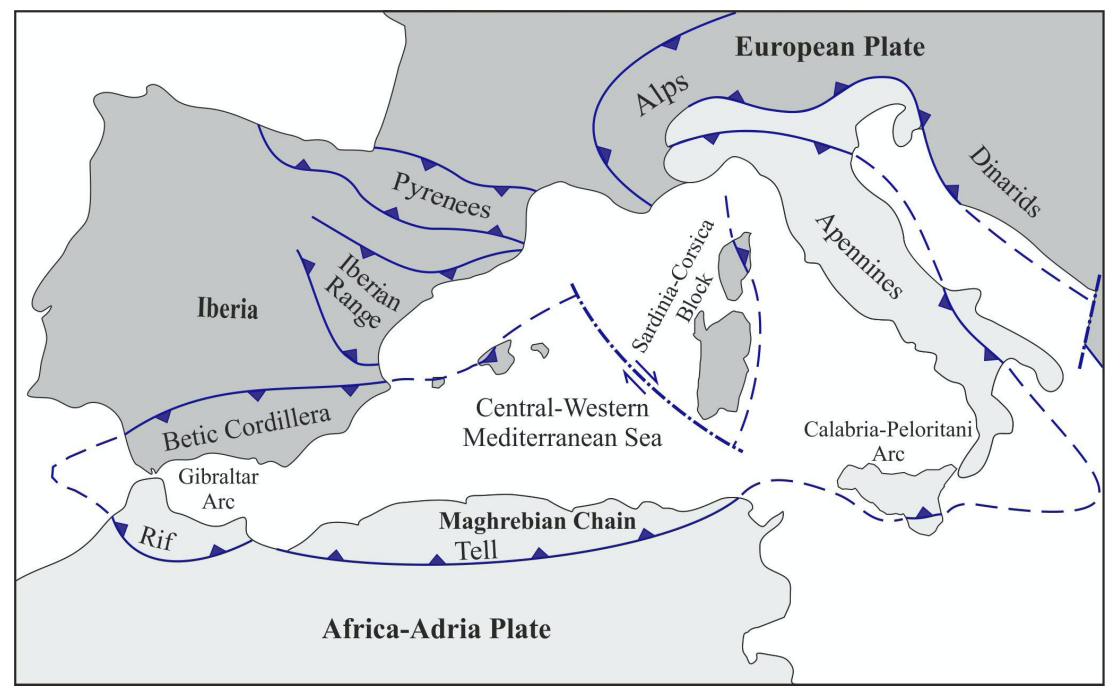

Figure 1. Simplified tectonic map of the central-western peri-Mediterranean chains (after [2], revised).

The considered area is, therefore, a key target for understanding the development of subduction zones that caused the closure of the basins and the development of the orogens. Therefore, special attention will be paid to this phenomenon in the following sections. In particular, the old subductions are recognized by the presence of HP-LT metamorphic rocks and ophiolite suites by means of targeted field reconstructions and petrographic-geochemical analyses. Furthermore, also geophysical and magmatological studies usually provide information on recent subductions. In fact, marked asymmetries in the crustal and lithospheric mantle structures are usually due to the existence of a subduction slab normally coincident at a certain depth with a positive anomaly of the P-wave velocity.

In the area, both continental and oceanic lithospheric elements were diachronously consumed along minor and major plate boundaries so not favoring the development of cylindrical phenomena, and, therefore, not easily recognized in the geological contexts considered. Really, the complex evolution of the area makes it difficult to reconstruct the geodynamic events as evidenced by the proliferation of different evolutionary models despite the many studies addressed to the subject.

It is quite clear that the methodological approach followed by different authors has a weight in the resulting interpretation; the following are also important: (i) the direct knowledge of the most significant segments of the chains considered; (ii) the quality and quantity of collected and considered data; (ii) the comparison with reliable data resulting from the reconstructions of other authors. 
In this section, some papers showing representative models have been selected for a comparison. They are considered as "key cases" both for the specificity of the used methodology and the results achieved about the paleogeographic and paleotectonic reconstructions of the main Cenozoic basins involved in the peri-Mediterranean chains (Betic-Maghrebian-Apennine system) development. The results will be considered based on parameters that allow delineating their relationships with the used methodology, to obtain useful indications and guidelines for future research.

Many geological models on paleogeographic, paleotectonic and geodynamic eo-Alpine and neo-Alpine evolution of the central-western Mediterranean area were published in the last four decades. However, remarkable differences still persist in the reconstruction of the main events at the different scales of phenomena.

In summary, it is not easy to answer to some questions that many researchers ask themselves, such as, for example: (i) With what confidence can a paleogeographic and/or paleotectonic reconstruction be considered? (ii) How is it possible to evaluate the quality of the data used for the reconstruction? (iii) How can the actual discriminant between direct (field and laboratory) and indirect data be found? (iv) Do field observations still have their essential and priority value? These are questions that researchers solve by means of their assessments carried out according to the knowledges concerning a certain topic and the choice of an appropriate methodological approach. To provide some answers to these questions, some selected papers, grouped according to the affinity of methodological investigation used, are examined below as key cases.

\subsection{Paleogeography-Based Models}

Historical models based on interdisciplinary data from classical geology (field observations, geological mapping, stratigraphy, lateral correlations, structural analysis, mineralogy and petrography, geochemistry, etc.) have provided paleogeographic and paleotectonic reconstructions of the Cenozoic basins included in the peri-Mediterranean chains. A first general reconstruction of the geological evolution of these basins was carried out by different authors ([3-6] among others). The main results are outlined in Figure 2. These reconstructions consider the occurrence of a single Tethyan oceanic branch separating the African-Adria Plate from the Iberia Plate from whose margin a continental block later detached to constitute the future Internal Zones of the Betic-Rifian-Tellian-Apennine chains. This type of interpretation was successively deepened and supported by different authors (see later).

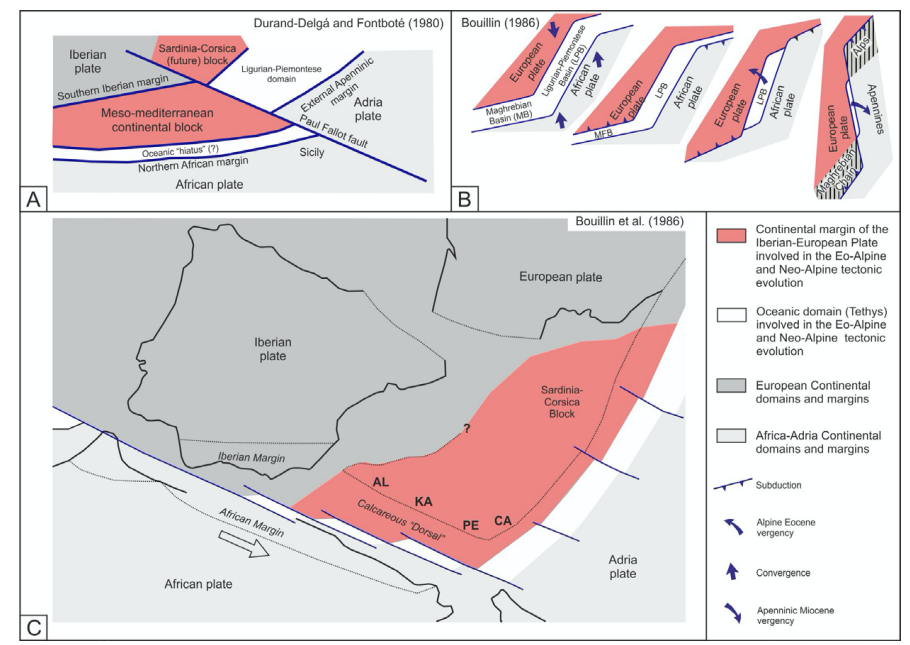

Figure 2. Reproduction of some paleogeographic and paleotectonic evolutionary models of the central-western peri-Mediterranean region (redrawn and simplified). (A) Jurassic evolution (After [4]); (B) From Cretaceous to Miocene (after [5]; (C) From Cretaceous to Miocene (after [6-9]): AL, Alboran; KA, Kabilides; PE, Peloritani; CA, Calabria. The reconstructions show two opposite subductions occurring in the same oceanic branch. 
New contributions based on similar approaches were provided later by different authors; particularly noteworthy are those of Wildi [10], who studied the stratigraphic and tectonic evolution of the Cenozoic basins involved in the Tell-Rif chains and Martín-Algarra [11], who proposed an Alpine evolution of the Internal and External Betic units along the contact zone.

Based on an interdisciplinary classical approach supported by lateral regional correlation, an evolutionary model was proposed by Guerrera et al. [12]. This model considers a general framework of the Late Oligocene-Miocene syn-/late-orogenic stratigraphic successions involved in the chains extending from the Betic Cordillera to the Southern Apennines, which is partially alternative to the previous interpretations. Starting from a late Jurassic paleogeography (beginning of the Alpine history), this model considers the presence of an intermediate and independent microplate, which was separated from the African and European continental margins by at least two western Tethyan oceanic branches (Figure 3). Numerous subsequent studies allowed to deepen and improve this model also with significant scientific contributions from research of different institutions. In fact, many papers developed and enriched the original idea with new and important contributions by means of different data and reconstructions ([13-37] among others and references therein).

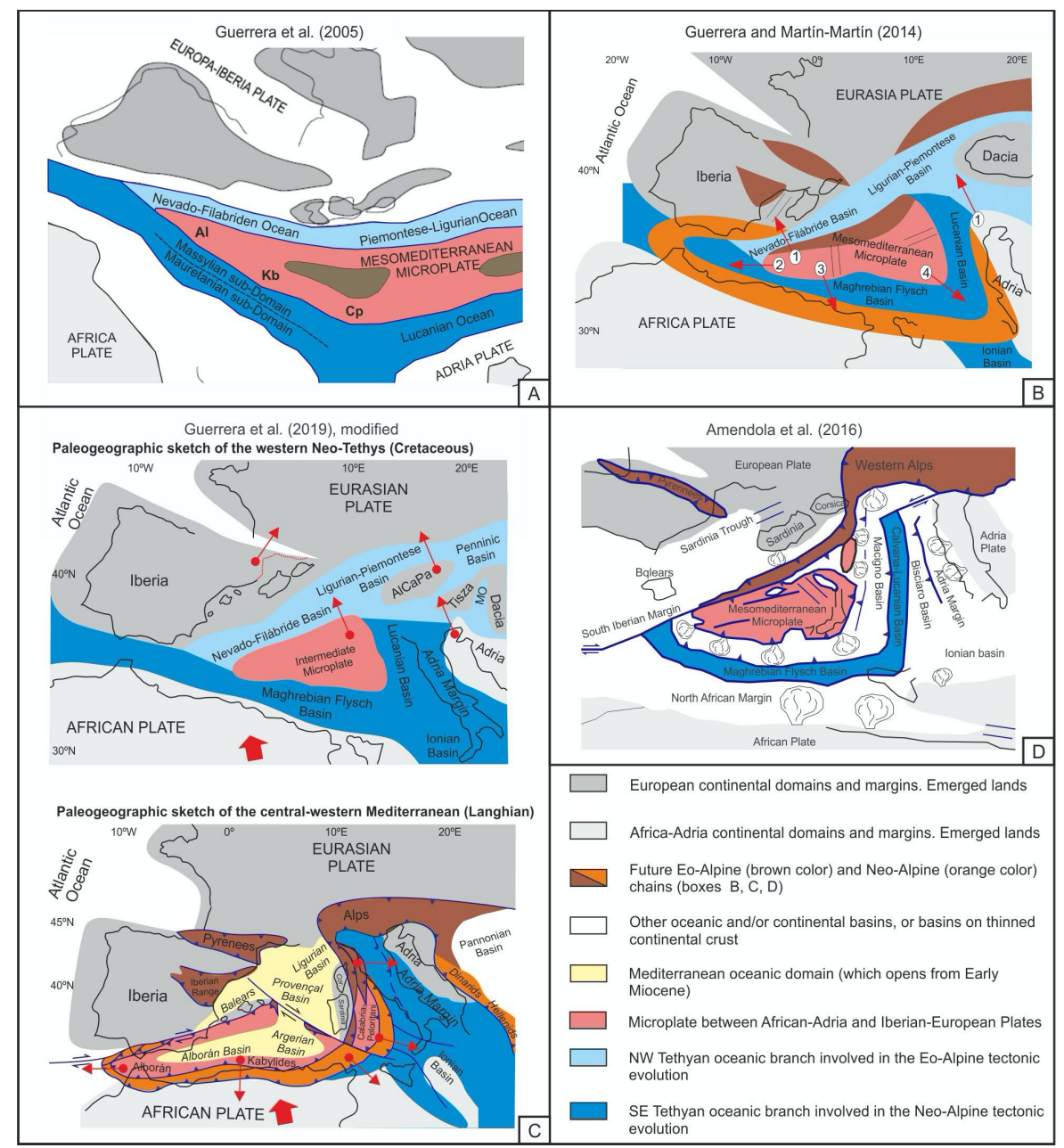

Figure 3. Redrawing of original figures showing the progressive improvements of paleogeographic and paleotectonic evolutionary models of the central-western Mediterranean region that consider the presence since Jurassic of two Tethyan oceanic branches separated by a microplate located between African and European Plates. Sketch maps showing the area in: (A), Cretaceous times (after [20], revised); (B), Cretaceous to Late Miocene (after [31], revised); (C), (two boxes), Cretaceous and Middle Miocene times (after [1], revised); (D), Early Miocene (after [32], revised). All reconstructions result from an interdisciplinary classical geology approach. 


\subsection{Plate Kinematics-Based Models}

Interpretations concerning the evolution of the central-western Mediterranean area have been also based on Plate Tectonics rules and processes and have been addressed to the reconstruction of the kinematics of different plates involved ([38-45], among others).

In general, these reconstructions concern the kinematics of continental blocks bounded by active faults, the temporal range of activity and rotational parameters. In particular, Schettino and Turco [42], Schettino and Turco [44] determined both the style and timing of back arc processes, calculated the Euler poles of the involved plates and presented information about the distribution of the oceanic crust and types of tectonic structures that are recognizable in the area. Magnetic field data useful to identify approximately the extension of the oceanic crust, the kinematics of transcurrent faults, fracture zones and other tectonic lineaments were also used to provide Plate Tectonics-based evolutionary models of the central-western Mediterranean region (Figure 4). These models appear to be useful in the case of presence of weak tectonic activity and when the boundaries of continental blocks are neither deformed nor affected by metamorphism. In these latter cases, reconstructions become very complex and difficult.

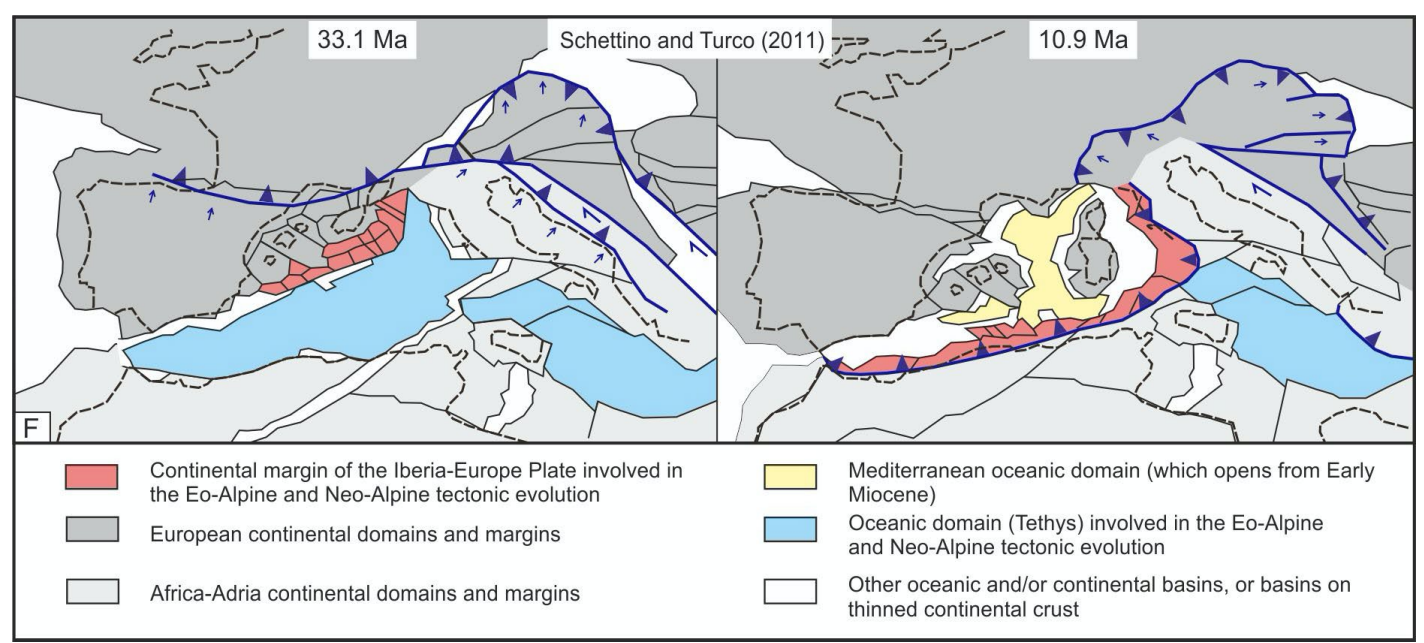

Figure 4. Reproduction of evolutionary paleogeographic sketch maps showing the evolution of the central-western Mediterranean region from $33.1 \mathrm{my}$ (late Cretaceous) to 10.9 my (late Miocene) and considering the presence of a single ocean between African and European Plates (elaboration according to Plate kinematics-based models; after [44], redrawn).

Since the 1990s, some computer software to create plate kinematics models were introduced and, recently ([46]), the free software GPlates (see Section 3.5) was developed to provide constraints for the reconstructions of plate evolution according to the rules of Plate Tectonics modelling.

Consequently several papers concerning the Mediterranean region and presenting modelling performed using the GPlates software were published recently (e.g., [47-50]) and also animations based on GPlates modelling can be found in websites ([51-53]). The obtained results were used to support evolutionary models of the central-western Mediterranean region; however, they do not always lead to coincident reconstructions. In fact, they allow different paleogeographic frameworks to be reconstructed, some of which support the presence of intermediate microplates located between the African and European Plates and others instead that provide for the presence of a single ocean between Europe and Africa.

\subsection{Tectonic and Magmatic Data-Based Models}

Progressive elaboration $([54,55])$ presented a geodynamic evolution of the Cenozoic basins of the central-western Mediterranean and surrounding areas during the last 50 my, mainly integrating different tectonic and magmatologic observations aimed to better identify the geodynamic events. 
In particular, the reconstruction of the geodynamic evolution results from the comparison between tectonics and igneous petrology constraints.

This model highlights that the magmatic evolution of the Cenozoic basins of the Mediterranean area inferred from the geochemical composition of the magmatic rocks linked to subduction zones cannot be easily reconciled with simple magmatological models proposed for the Pacific subductions. In fact, the classic approach based on the geochemical composition of magmatic rocks to interpret the synchronous tectonic features cannot be used in complex geological systems such as the Mediterranean area. These authors considered this aspect as related both to the contemporary activity of Cenozoic subduction zones that strongly modified the chemical composition of the upper mantle and mostly to the presence of ancient modifications linked to the previous orogeny. The evolution proposed by these authors is represented by different figures reported in their paper, and they are partially and schematically reproduced in Figure 5.

The relationship between calc-alkaline volcanism and tectonic setting has been used to reconstruct episodes of the western-Mediterranean-Tyrrhenian oceanic opening ([56]). This approach highlights a detailed reconstruction of the main volcano-tectonic events from early Oligocene up to late Pliocene. Space-time features indicate that calcalkaline volcanism is not linked only to subduction because a temporal gap would exist between the steep subduction beneath the Apennines and the previous, flat-type plunge subduction beneath of the European plate, which have an opposite direction and produce the accretion of the Alpine age orogen and the double vergence. The reconstructed events show continuum phenomena not strictly related to the main orogenic phases (late Alpine, Apennine-Maghrebian and later phases) usually recognized and used as geodynamic evolution reference.

A reconstruction based on geochemical-petrographic data of volcaniclastic rocks of the northern Apennine was utilized to propose an evolutionary model of the Cenozoic basins of the Mediterranean area ([57]). The geodynamic phases reconstructed in the Cenozoic would have been controlled by different subduction slabs that led the authors to an original reconstruction of the orogenic elements involved. In fact, the paleogeographic-geodynamic evolution proposed is very different with respect to reconstructions based on interdisciplinary studies concerning the regional geology of the central-western Mediterranean area and which establish, in our opinion, some important constraints ([2], and references therein). 


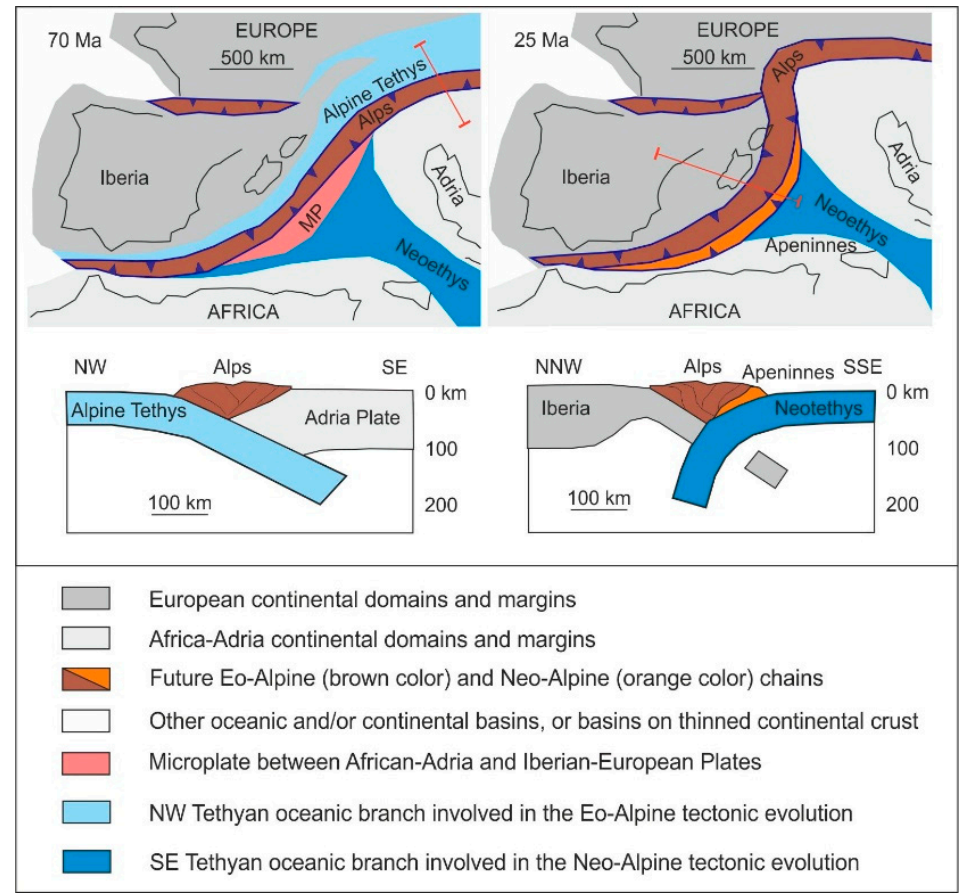

Figure 5. Reproduction of evolutionary paleogeographic and paleotectonic sketch maps of the central-western Mediterranean and schematic geological sections of the area in the latest Cretaceous (70 my) and latest Oligocene (25 my), (after [54]) and considering on the basis of previous studies (i.e., [58], [9], among others) the presence of two oceanic branches separated by a microplate located between African and European plates.

\subsection{Geophysical Study-Based Models}

By means of geophysical interpretations concerning the peri-Mediterranean Cenozoic basins evolution, different subduction models were considered: (i) delamination and slab roll-back processes [59-62]; (ii) convective removal of mantle lithosphere [63,64]; (iii) partial or total break-off and/or tearing $[47,65,66]$. A part of geophysical studies showed a marked asymmetry in the crustal and lithospheric mantle structures along the Gibraltar Arc region, between the south-Iberia and north-Morocco margins. These features coincide with a positive anomaly of the P-wave velocity at a certain depth, which is interpreted as related to a relict of a detached subduction slab below the Betic-Rif orogen. Platt and Vissers [67] proposed a Miocene extensional collapse of the Gibraltar Arc area after the continental thickening related to subduction and collision of blocks during the Paleogene.

Most of these papers proposed a single W- to NW-directed subduction of the African Plate beneath the Betic system, which fits perfectly with the Miocene evolution and closure of the Maghrebian Flysch Basin. Instead, these studies did not provide information about previous subduction processes (i.e., the closure of NF-LP Ocean) responsible for the formation of Alps and that on the contrary are well documented by models pointing out a double and opposite subduction which causes at different times the development of the Alpine Chain (Cretaceous-Paleocene) and Apennine-Maghrebian Chain (Oligo-Miocene). Really, the occurrence of the oldest subduction is mainly based on the presence of HP-LT metamorphic rocks and ophiolite suites, which were supposed to have formed further away to the East of their current position (i.e., [31,34,54,61], among others). Probably, this older subduction slab was later interrupted, laminated and removed during the Oligocene to Early Miocene by a NW-SE strike-slip fault zone, which displaced the crustal block towards W, to reach its present position $([3,4,35,68,69]$ among others). Considering the time elapsed and the total displacement, the inexistence of geophysical evidence for these subduction mechanisms can be explained considering the detaching and melting of the subduction slab, and the resorption by convective flows during magma production [70]. 


\subsection{Paleomagnetic Study-Based Models}

When they exist, paleomagnetic data available at the regional scale constitute the most rigorous way to restore the paleo-positions of the continents associated to oceanic openings [71]. Some important papers aimed to paleogeographic reconstructions based on paleogmagnetic data have been published about the study area in a specific sector or at the regional Mediterranean scale. Therefore, Lowrie and Alvarez [72] studied the rotation of the Italian Peninsula during the Cretaceous to Eocene period in the Umbria Apennines scaglia-like sediments. Scheepersa et al. [73] analyzed marine marls of the middle Pleistocene by proposing a clockwise rotation of the Calabria-Peloritani block (South Italy). Studies at the scale of the Mediterranean aimed to the study of the Tertiary extensional basins within the Alpine orogeny using paleomagnetic approach have been also proposed by Durand et al. [74] and Jolivet and Faccenna [75].

Furthermore, some of the above mentioned Plate kinematics-based models [41-44] use also paleomagnetic data to identify the extension of the oceanic crust, the kinematics of transcurrent faults, fracture zones and other tectonic lineaments during the oceanic opening. Nevertheless, these goals seem to be achievable for continental blocks which still today maintain a similar shape (Balearic Islands, Corsica-Sardinia Block, etc.). Furthermore, after a subduction the continental blocks usually form part of an orogenic chain and through the collision become part of nappes, being affected by thrusts, folds and metamorphism. In these very common cases, it becomes very difficult to restore and to reconstruct the events and their development by means of paleomagnetic studies and, therefore, other types of studies must be applied.

\subsection{Underlining the Tool GPlates Software}

The abovementioned GPlates software is a free software for calculation and interactive 2D-3D visualization, which has been recently introduced [46,49-51] for Plate Tectonics reconstructions. GPlates software allows displaying geological reconstructions for a single moment of geological timeline or through animate sequences over a defined geological period. The software also allows time-derivative information (plate-motion velocity fields and flowlines) to be calculated, and sometimes data were exported into other geospatial software for further elaboration. Some examples of the Cenozoic basins of the central-western Mediterranean area have been realized. These reconstructions show the evolutionary steps of different geodynamic frameworks characterized by a single subduction (providing for a single oceanic branch of the Tethys) or by two opposite subductions (presence of two Tethyan oceanic branches separated by an intermediate microplate) involving the Africa-Adria and European margins.

GPlates software was used for investigations addressed to correlate geological elements (points, lines and polygons) during changes both of their relative position and of deformation style, and to define time dependent elements based on Plate Tectonics assumptions. This particular approach results in the possibility to elaborate different models for a single region. The fundamental differences are represented by: (1) the initial configuration of tectonic elements; (2) criteria used to determine the finite reconstruction poles; and (3) geological features (tectonics, stratigraphy, volcanism, etc.) considered in different times. Therefore, applying only this software does not always help to decide the best reconstruction. As GPlates reconstructions for the central-western Mediterranean Cenozoic basins are based on rigid plate models, the final results are highly influenced by the starting model used (e.g., [25,47-49]) in different types of GPlates animations.

\section{Discussion and Final Remarks}

Geological models of the central-western Mediterranean area often are not easily integrated because they are based on different types of data sets collected using different methodological approaches and differently processed. A major problem for a better understanding of the geodynamic evolution of the Cenozoic basins of this region is often related to the achievement of results by means 
of single disciplines (geology, stratigraphy, geophysics, tectonics, magmatology, plate kinematics, etc.), applying their own specific methodological approach instead of using a multidisciplinary approach which would ensure a greater control of data and a major degree of validation for the reconstruction of geodynamic events and related models.

Some of the models mentioned in Section 3 result from very different methodological approaches and testify this necessity. However, it is necessary to point out that in some cases also interdisciplinary-based geological models do not take into account fundamental constraints resulting from other disciplines (e.g., geophysics or magmatology).

Anyhow we believe that all reconstructions at all scales and levels of detail are valid but the lack of a direct and/or indirect "contact" with rocks and field geology often results in a data deficit that should suggest a greater interpretative caution. In our opinion this "contact" cannot be lost because the recognizable geological history is always contained in the rocks even if insuperable interpretative limits are represented by: (i) a large part of the information on geological history has been destroyed by Earth geodynamics (i.e. successive orogenic phases, etc.); (ii) the rocks analyzed are only a very small part of the existing ones.

For the abovementioned reasons, the models should be born with the greatest multidisciplinary approach possible and without underestimating constraints imposed by previous interpretations, especially when the latter offer results related to the analysis of rocky successions with the maximum temporal resolution which would support a more defined reconstruction of geological events.

An example of marked interpretative differences still remaining in the geological literature of the Mediterranean area concerns the reconstruction of the paleogeographic setting after the Hercynian cycle.

In fact, a part of models reconstructs a geological history where the main actors are the margins of the main plates (Europe and Africa-Adria), which are separated by a single Tethyan oceanic branch. In this context, the Alpine history would be accomplished (Eo-alpine, Cretaceous; Meso-alpine, Paleocene; Neo-alpine, Neogene; phases) by means of various tectonic mechanisms followed away by an Apennine-Maghrebian history. These models allow to a relatively simpler interpretative solution with some difficulty of recognition about the distinction of the two different stories because the Alps and Maghrebian-Apennine chains are considered continuous and hinged to the same original paleogeographic framework.

Another part of models, and in particular those based on an interdisciplinary approach including different fields of classical geology (but not only), considers a more complex post Hercynian paleogeography characterized by the presence of one or more microplates. An example is represented by the Mesomediterranean Microplate that represents an area, located since Jurassic between the African and European Plates to separate at least two oceanic (or with thinned continental crust) branches of the western Tethys. The Alpine System s.s. developed during the Cretaceous-Eocene from the western branch (i.e., the Ligurian Piemontese-Nevado Filabride Ocean) while the post-Alpine System, which is represented by the Miocene Betic-Maghrebian-Apennine orogenic belt originated from the eastern branch (Maghrebian Ocean). So the intermediate microplate participated in the orogenic evolution as an internal zone first in the eo-Alpine history (subduction towards SE) and successively in the neo-Alpine Apennine-Maghrebian evolution (subduction towards NW. Therefore, marked and not easily reconciled paleogeographic and paleotectonic differences exist between the two groups of models. For example, the Mesomediterranean Microplate should not be confused with the $\mathrm{AlKaPeCa}$, the latter corresponding in the original definition to a continental block originated and separating from the European Margin during the neo alpine Maghrebian-Apennine evolution. Moreover, also the specific events (reconstruction based on stratigraphic records, magmatic events, geological cycles, tectonic phases, age, etc.) considered in different models show important differences.

As commented above, some methods (i.e., models based on geophysics, paleomagnetic data and Plate kinematics) are applicable when the effect of tectonics is low or for recent phenomena, but the task is much more difficult after strong deformation when superimposed subductions occur and the stratigraphic record is partially or totally metamorphosed. The magmatic data-based models are 
limited to areas with the described types of magmatic suite and the GPlates software models are highly influenced by the initial model introduced in the software. So, interpretative models should be born as a result of the broadest multidisciplinary approach possible. Taking into account the lack of homogeneity between the many models, an attempt to trace an evolutionary framework for the Cenozoic basins of the central-western Mediterranean area has been carried out, trying to merge the main results from different methodological approaches that are somewhat "dialoguing". With this premise and assumptions, we favored models based mainly on data obtained using the good interdisciplinary practices of classical geology integrated and completed with other data resulting from models based on different approaches as much as possible. In our view, this multidisciplinary approach leads to a better understanding of the subduction processes, collision, and oceanic opening and spreading in the central-western Mediterranean area associated to the birth of the Alpine chains.

In the considered context, related to the reconstruction of the geodynamic evolutionary framework of a Tethyan sector, and in particular of the chains of the central-western Mediterranean area that results from the evolution of this sector, the models providing for a more complex paleogeography are to be considered more complete. In fact, the presence of different oceanic branches to separate one or more microplates rather than the occurrence of a single oceanic area seems to be more suitable to explain the compressive development of the chains. This type of reconstruction seems to result more frequently from multidisciplinary elaborations carried out through classical geology investigations, which consider field activities carried out in different sectors of the studied chains as an essential starting point of the work and to which the highest number of different analyses are associated. This path allows the reconstruction of an evolutionary paleogeographic and paleotectonic framework to be accomplished, considering as much data as possible, and also pointing out all the recognized events with the greatest detail.

Without diminishing the importance of differently-based alternative models that maintain their absolute validity, this choice is conditioned, above all, by the high-level resolution of the temporal reconstruction of events and by the use of data from direct analyses of rocks; this is because only rocks contain the real data recording of the geological evolution and history. The different interpretative models concerning the central-western Mediterranean chain systems allowed focusing evolutionary reconstructions based on sufficiently verified main geological events. Other methodological approaches led to formulate conceptually different complex evolutionary models derived without mutual comparisons and data integrations.

A paleogeographic and paleotectonic interpretation representing an upgrading of previous reconstructions is presented (Table 1). This reconstruction takes into account new data from different sectors of the considered chains, especially concerning the Rif Chain. The main geological and geodynamic events recognized in the examined peri-Mediterranean chains are schematically reported in Table 1. The reconstruction is mainly based on previous multidisciplinary studies from our Research Group that were carried out according to a classical geology approach. 
Table 1. Main geodynamic events in the eo- and neo-Alpine systems from Triassic to Pliocene recognized in different sectors of the central-western peri-Mediterranean chains (after $[1,2,37,76])$.

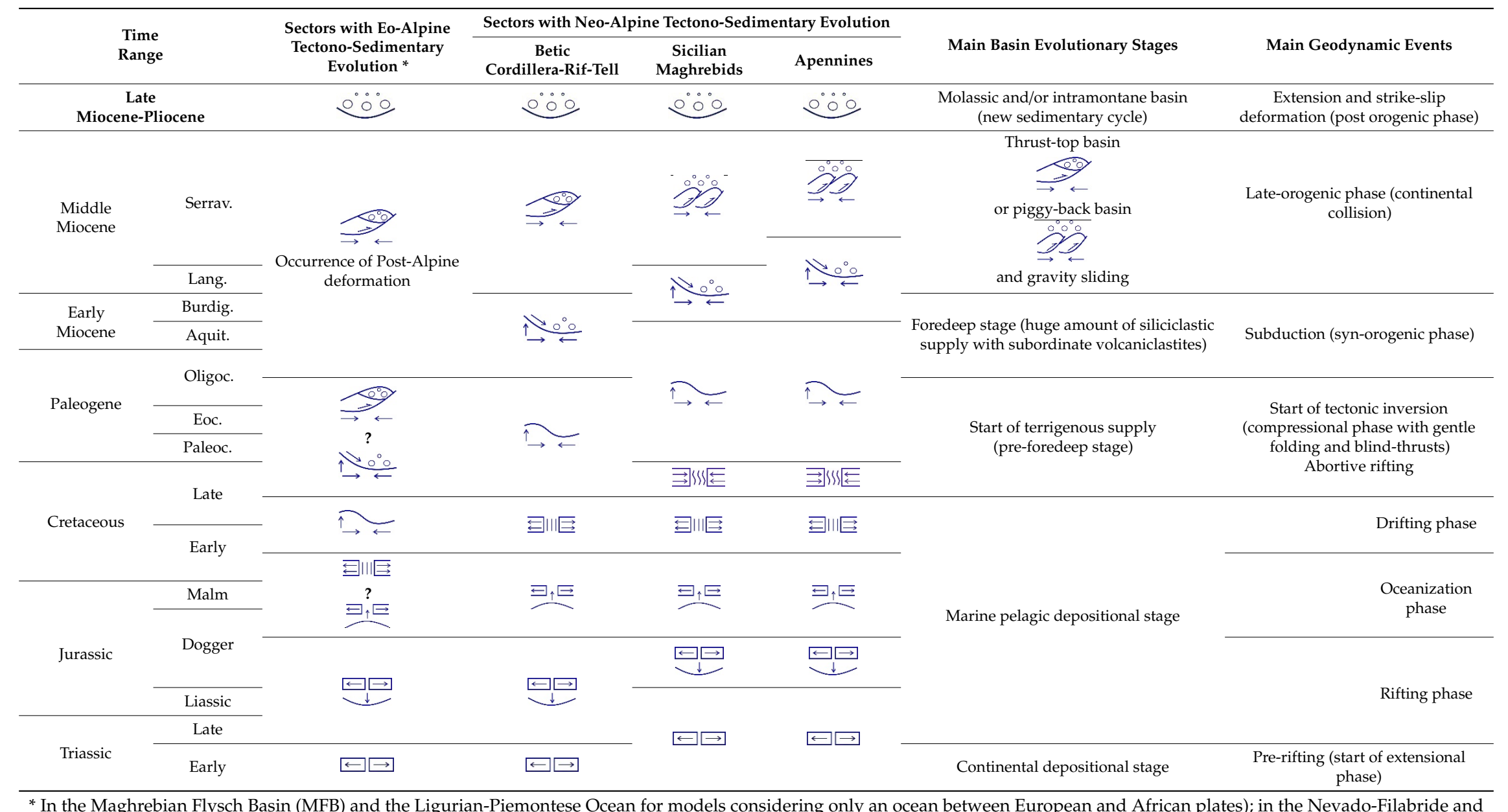

* In the Maghrebian Flysch Basin (MFB) and the Ligurian-Piemontese Ocean for models considering only an ocen
Ligurian-Piemontese Oceans for models considering two oceans at least between European and African plates. 
In Figure 6, a general late-Jurassic-early Cretaceous paleogeographic sketch map is proposed. This interpretation shows the main elements and domains of the Mediterranean Tethyan region that resulted from the Hercynian evolution and after which the eo-Alpine and neo-Alpine hystory begins (after [37], modified). The paleotectonic evolution is also represented by means of seven very simplified sections (box B). These sections synthetically show the main crustal elements (oceans, continents and sedimentary covers); subduction planes; main tectonic movements; and orogenic phases.

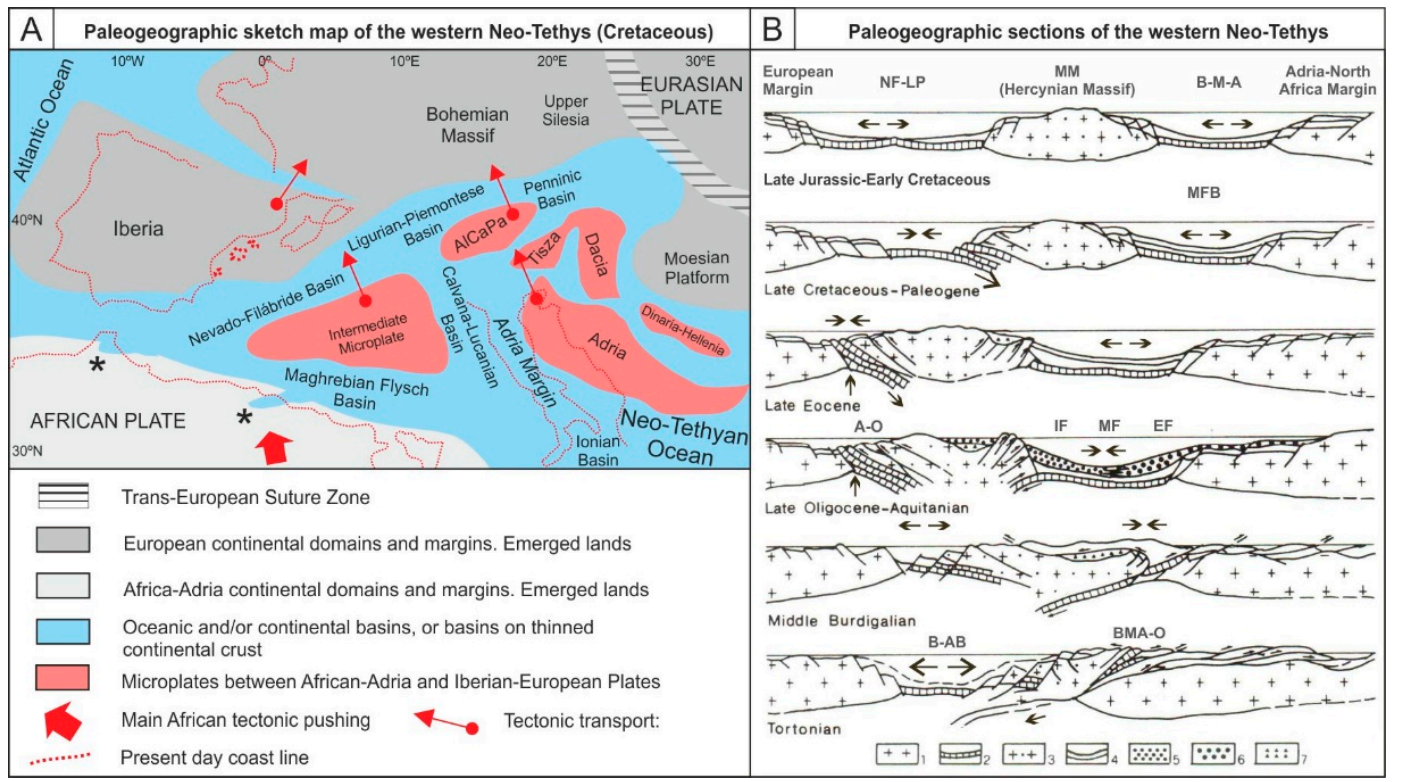

Figure 6. Simplified paleogeographic sketch map in the late Jurassic-early Cretaceous representing the main features and domains of the central-western Mediterranean Tethyan area (Box A); seven synthetic sections showing the main crustal elements (oceans, continents and sedimentary covers), subduction zones, main tectonic movements and orogenic phases representative of the evolution of eo-alpine and neo-alpine systems (Box B) are also shown. Key: NF-LP, Nevado Filabride-Ligurian Piemontese Basins; B-M-A, Betic-Maghrebian-Apennines; MFB, Maghrebian Flysch Basin; IF, Internal Flysch (MFB); MF, Mixed Flysch (MFB); EF, External Flysch (MFB); B-AB, Back-Arc basins; BMA-O, Betic Maghrebian Apennine orogen; 1, Continental crust of the European and African margins; 2, Oceanic crust; 3, Continental crust of the Mesomediterranean Microplate (MM); 4, Meso-Cenozoic sedimentation; 5, Syn-orogenic flysch deposits (MFB); 6, Numidian deposits (MFB); 7, Late-orogenic flysch deposits.

Relationships between microplates and basins, tectonic transport, and opening and closing of basins are also shown (data from $[9,21,31,37,69,77,78]$ ). In the reconstruction the Tethyan oceanic branch recently recognized in the External Domain of the Rif Chain $([35,79-81])$ was interpreted as an oceanic branch sector located between the External zones of the Mesorif and Intrarif Domains connected to the Maghrebian Flysch Domain [82].

In summary, some models concerning the paleogeographic, paleotectonic and geodynamic evolution of the eo-Alpine and neo-Alpine chains of the Mediterranean region have been revised considering the relationships between different methodological approaches, results and interpretations.

The main differences in the proposed models concern the kinematic reconstructions and the paleogeographic and paleotectonic evolution of the area and mainly depend on the utilized study method. In our opinion the most important differences area as follows: (1) the differences in the late Jurassic-Early Cretaceous paleogeography mainly resulting in the presence of one or more Tethyan branches between the European and African-Adria margins. More branches imply the occurrence of one (or more) microplates between Europe and Africa-Adria; (2) the kinematic mechanisms that caused the stacking of the different tectonic units (internal, intermediate and external units) and the 
resulting opposite vergence of the chains (Alps, Betics, Maghrebids and Apennines) mainly due to the evolutionary transition from the eo-Alpine to Neo-Alpine phase; (3) the age and distribution of the oceanic crust in the different Tethyan branches and related tectonic units, especially in the Maghrebian Basin; (4) the timing of events. A modern biostratigraphy allows to a high temporal resolution especially when studies are integrated with other disciplines.

A more appropriate terminological use during the reconstruction of evolutionary models is also desirable to avoid not comply interpretations. A concrete example is provided by the often improper use of the acronym AlKaPeKa (introduced by [5] to group Alboran, Kabylides, Peloritani and Calabria domains) that originally belongs to the Iberian margin, also for the "Mesomediterranean microplate" ([1] and references therein) that instead represents an individual microplate.

Finally, the presented discussion on the different methodological approaches can help to clarify some controversial aspects on the considered subject.

Author Contributions: All the authors contributed to the different parts of the article. All authors have read and agreed to the published version of the manuscript.

Funding: Research supported by: grants from the University of Urbino Carlo Bo (F. Guerrera and M. Tramontana); Research Project CGL2016-75679-P, Spanish Ministry of Education and Science; Research Groups, Projects of the Generalitat Valenciana, Alicante University (CTMA-IGA).

Acknowledgments: Authors wish to acknowledge two anonymous referees for useful comments and suggestions.

Conflicts of Interest: The authors declare no conflict of interest.

\section{References}

1. Guerrera, F.; Manuel Martín-Martín, M.; Tramontana, M. Evolutionary geological models of the Central-Western Peri-Mediterranean chains: A review. Int. Geol. Rev. 2019. [CrossRef]

2. Martín-Martín, M.; Guerrera, F.; Tramontana, M. Geodynamic implications of the latest Chattian-Langhian Central-Western Mediterranean volcano-sedimentary event: A review. J. Geol. 2020, 128, 29-43. [CrossRef]

3. Durand Delga, M. La Méditerranée occidentale: étapes de sa genèse et problèmes structuraux liés à celle-ci. Mem. H.-Sér. Soc. Géol. 1980, 10, 203-224.

4. Durand Delga, M.; Fontboté, J.M. Le cadre structural de la Méditerranée occidentale. Mém. BRGM 1980, 115, 67-85.

5. Bouillin, J.P. Le “bassin maghrébin": Une ancienne limite entre l'Europe et l'Afrique à l'ouest des Alpes. Bull. Soc. Geol. Fr. 1986, 2, 547-558. [CrossRef]

6. Bouillin, J.P.; Durand Delga, M.; Olivier, P. Betic-Rifian and Tyrrhenian arcs: Distinctive features, genesis and development stages. In The Origin of Arcs; Wezel, F., Ed.; Elsevier: Amsterdam, The Netherlands, 1986; pp. 321-338.

7. Vitale, S.; Zaghloul, M.N.; Tramparulo, F.D.A.; El Ouaragli, B.; Ciarcia, S. From Jurassic extension to Miocene shortening an example of polyphasic deformation in the External Dorsale Calcaire Unit (Chefchaouen, Morocco). Tectonophysics 2014, 633, 63-76. [CrossRef]

8. Vitale, S.; Zaghloul, M.N.; Tramparulo, F.D.A.; El Ouaragli, B. Deformation characterization of a regional thrust zone in the northern Rif (Chefchaouen, Morocco). J. Geodyn. 2014, 77, 22-38. [CrossRef]

9. Vitale, S.; Zaghloul, M.N.; El Ouaragli, B.; Tramparulo, F.D.A.; Ciarcia, S. Polyphase deformation of the Dorsale Calcaire Complex and the Maghrebian Flysch Basin Units in the Jebha area (Central Rif, Morocco): New insights into the Miocene tectonic evolution of the Central Rif belt. J. Geodyn. 2015, 90, 14-31. [CrossRef]

10. Wildi, W. La chaîne tello-rifaine (Algérie, Maroc, Tunisie): Structure, stratigraphie et évolution du Trias au Miocène. Rev. Géol. Dyn. Géogr. Phys. 1983, 24, 201-297.

11. Martín-Algarra, A. Evolucion Geologica Alpina del Contacto Entre las Zonas Internas y las Zonas Externas de la Cordillera Bética (Sector Centro-Occidental). Ph.D. Thesis, University of Granada, Granada, Spain, 1987.

12. Guerrera, F.; Martín-Algarra, A.; Perrone, V. Late Oligocene-Miocene syn-/late-orogenic successions in western and central Mediterranean chains from the Betic cordillera to the southern Apennines. Terra Nova 1993, 5, 525-544. [CrossRef] 
13. Durand Delga, M.; Rossi, M.; Olivier, P.; Puglisi, D. Situation structurale et nature ophiolitique des roches basiques jurassiques associées aux flychs maghrébins du Rif (Maroc) et de Sicile (Italie). Comptes Rendus de 1'Académie des Sci. -Ser. IIA-Earth Planet. Sci. 2000, 331, 29-38.

14. Frizon de Lamotte, D.; Saint Bezar, B.; Bracène, R.; Mercier, E. The two main steps of the Atlas building and geodynamics of the western Mediterranean. Tectonics 2000, 19, 740-761. [CrossRef]

15. Plesi, G.; Galli, M.; Daniele, G. The Mts Rognosi Ophiolithic unit (cfr. Calvana unit Auct.): Paleogeographic position in the External Ligurian domain, relationships with the tectonic units derived from Adriatic margin. Boll. Soc. Geol. Italy 2002, 1, 273-284.

16. Bonardi, G.; de Capoa, P.; Di Staso, A.; Estevez, A.; Martín-Martín, M.; Martín-Rojas, I.; Perrone, V.; Tent-Manclús, J.E. Oligocene-to-Early Miocene depositional and structural evolution of the Calabria-Peloritani Arc southern terrane (Italy) and geodynamic correlations with the Spain Betics and Morocco Rif. Geodyn. Acta 2003, 16, 149-169. [CrossRef]

17. de Capoa, P.; Di Staso, A.; Guerrera, F.; Perrone, V.; Tramontana, M. The extension of the Maghrebian Flysch Basin in the Apenninic Chain: Paleogeographic and paleotectonic implications. Atti Congr. "Etat des connaissances géologiques des régions nord du Maroc: La Chaîne Rifaine dans son cadre Méditérranéen occidental, Rabat (Maroc). Trav. Inst. Sci. Rabat Géografie Phys. 2003, 21, 77-92.

18. de Capoa, P.; D’Errico, M.; Di Staso, A.; Perrone, V.; Perrotta, S.; Tiberi, V. The succession of the Val Marecchia Nappe (Northern Apennines, Italy) in the light pf new field and biostratigraphic data. Swiss J. Geosci. 2015, 108, 35-54. [CrossRef]

19. Roca, E.; Frizon De Lamotte, D.; Mauffret, A.; Bracène, R.; Vergés, J.; Benaouali, N.; Fernandez, M.; Muñoz, J.A.; Zeyen, H. TRANSMED transect II. In The Transmed Atlas; Cavazza, W., Roure, F.M., Spakman, W., Stampfli, G.M., Ziegler, P.A., Eds.; Springer: Berlin, Germany, 2004; pp. 1-141.

20. Guerrera, F.; Martín-Martín, M.; Perrone, V.; Tramontana, M. Tectono-sedimentary evolution of the southern branch of the western Tethys (Magrebian Flysch basin and Lucanian ocean). Terra Nova 2005, 17, 358-367. [CrossRef]

21. Guerrera, F.; Martín-Algarra, A.; Martín-Martín, M. Tectono-sedimentary evolution of the "Numidian Formation" and Lateral Facies (southern branch of the western Tethys): Constraints for Central-Western Mediterranean geodynamics. Terra Nova 2012, 24, 34-41. [CrossRef]

22. Guerrera, F.; Martín-Martín, M.; Raffaelli, G.; Tramontana, M. The Early Miocene "Bisciaro volcaniclastic event" (northern Apennines, Italy): A key study for the geodynamic evolution of the Central-Western Mediterranean. Int. J. Earth Sci. 2015, 104, 1083-1106. [CrossRef]

23. Michard, A.; Negro, F.; Saddiqi, O.; Bouybaouene, M.L.; Chalouan, A.; Montigny, R.; Goffé, B. Pressure-temperature-time constraints on the Maghrebide mountain building: Evidence from the Rif-Betic transect (Morocco, Spain), Algerian correlations, and geodynamic implications. C. R. Geosci. 2006, 338, 92-114. [CrossRef]

24. Perrone, V.; Martín-Algarra, A.; Critelli, S.; Decandia, F.A.; D’Errico, M.; Estevez, A.; Iannace, A.; Lazzarotto, A.; Martín-Martín, A.; Martín-Rojas, I.; et al. "Verrucano" and "Pseudoverrucano" in the Central-Western Mediterranean Alpine Chains: Paleogeographical evolution and geodynamic significance. In Tectonics of the Western Mediterranean and North Africa; Chalouan, A., Moratti, G., Eds.; Geological Society of London: London, UK, 2006; Volume 262, pp. 1-43.

25. Handy, M.R.; Schmid, S.M.; Bousquet, R.; Kissling, E.; Bernoulli, D. Reconciling plate-tectonic reconstructions of Alpine Tethys with the geological-geophysical record of spreading and subduction in the Alps. Earth-Sci. Rev. 2010, 102, 121-158. [CrossRef]

26. Critelli, S.; Muto, F.; Tripodi, V.; Perri, F. Relationships between lithospheric flexure, thrust tectonics and stratigraphic sequences in foreland setting: The Southern Apennines foreland basin system, Italy. Tectonics 2011, 2, 121-170.

27. Critelli, S.; Muto, F.; Tripodi, V.; Perri, F. Link between thrust tectonics and sedimentation processes of stratigraphic sequences from the southern Apennines foreland basin system, Italy. Rend. Online della Soc. Geol. Ital. 2013, 25, 21-42.

28. Critelli, S. Provenance of Mesozoic to Cenozoic Circum-Mediterranean sandstones in relation to tectonic setting. Earth-Sci. Rev. 2018, 185, 624-648. [CrossRef] 
29. Alcalá, F.J.; Guerrera, F.; Martín-Martín, M.; Raffaelli, G.; Serrano, F. Geodynamic implications derived from Numidian-like distal turbidites deposited along the Internal-External domain boundary of the Betic cordillera (S Spain). Terra Nova 2013, 26, 119-129. [CrossRef]

30. Vitale, S.; Ciarcia, S. Tectono-stratigraphic and kinematic evolution of the southern Apennines/CalabriaPeloritani Terrane system (Italy). Tectonophysics 2013, 583, 164-182. [CrossRef]

31. Guerrera, F.; Martín-Martín, M. Geodynamic events reconstructed in the Betic, Maghrebian, and Apennine Chains (Central-Western Tethys). Bull. Soc. Geol. Fr. 2014, 185, 329-341. [CrossRef]

32. Amendola, U.; Perri, F.; Critelli, S.; Monaco, P.; Cirilli, S.; Trecci, T.; Roberto Rettori, R. Composition and provenance of the Macigno formation (Late Oligocene-Early Miocene) in the Trasimeno Lake area (Northern Apennines). Mar. Pet. Geol. 2016, 69, 146-167. [CrossRef]

33. Khomsi, S.; Frizon de Lamotte, D.; Mourad Bédir, M.; Echihi, O. The late Eocene and late Miocene fronts of the Atlas Belt in eastern Maghreb: Integration in the geodynamic evolution of the Mediterranean Domain. Arab. J. Geosci. 2016, 9, 1-20. [CrossRef]

34. Puga, E.; Díaz de Federico, A.; Fanning, M.; Nieto, J.M.; Rodríguez Martínez-Conde, J.A.; Díaz Puga, M.A.; Lozano, J.A.; Bianchini, G.; Natali, C.; Beccaluva, L. The Betic Ophiolites and the Mesozoic Evolution of the Western Tethys. Geosciences 2017, 7, 31. [CrossRef]

35. Leprêtre, R.; Frizon de Lamotte, D.; Combie, R.V.; Gimeno-Vives, O.; Mohn, G.; Eschard, R. The Tell-Rif orogenic system (Morocco, Algeria, Tunisia) and the structural heritage of the southern Tethys margin. Bull. Soc. Geol. Fr. 2018, 189, 10. [CrossRef]

36. Martín-Martín, M.; Guerrera, F.; Rodriguez-Estrella, T.; Serrano, F.; Alcalà, F.J.; Raffaelli, G.; Tramontana, M. Miocene tectono-sedimentary evolution of the eastern external Betic Cordillera (Spain). Geodin. Acta 2018, 30, 265-285. [CrossRef]

37. Martín-Martín, M.; Guerrera, F.; Miclaus, C.; Tramontana, M. Similar Oligo-Miocene tectono-sedimentary evolution of the Paratethyan branches represented by the Moldavidian Basin and Maghrebian Flysch Basin. Sediment. Geol. 2020, 396, 105548. [CrossRef]

38. Bullard, E.C.; Everett, J.E.; Smith, A.G. The fit of the continents around the Atlantic: A symposium on continental drift: Philosophical Transaction of the Royal Society of London. Ser. A Math. Phys. Sci. 1965, 258, 41-51.

39. Smith, A.G. Alpine deformation and the oceanic areas of the Tethys, Mediterranean, and Atlantic. Geol. Soc. Am. Bull. 1971, 82, 2039-2070. [CrossRef]

40. Rosenbaum, G.; Lister, G.S.; Duboz, C. Reconstruction of the tectonic evolution of the western Mediterranean since the Oligocene. J. Virtual Explor. 2002, 8, 107-130. [CrossRef]

41. Rosenbaum, G.; Lister, G.S. Formation of arcuate orogenic belts in the western Mediterranean region. In Orogenic Curvature: Integrating Paleomagnetic and Structural Analyses; Sussman, A.J., Weil, A.B., Eds.; Geological Society of America: Boulder, CO, USA, 2004; Volume 383, pp. 41-56.

42. Schettino, A.; Turco, E. Plate kinematics of the Western Mediterranean region during the Oligocene and Early Miocene. Geophys. J. Int. 2006, 166, 1398-1423. [CrossRef]

43. Schettino, A.; Turco, E. Breakup of Pangea and plate kinematics of the central Atlantic and Atlas regions. Geophys. J. Int. 2009, 178, 1078-1097. [CrossRef]

44. Schettino, A.; Turco, E. Tectonic history of the western Tethys since the Late Triassic. Geol. Soc. Am. Bull. 2011, 123, 89-105. [CrossRef]

45. Chalouan, A.; Michard, A. The Alpine Rif Belt (Morocco): A case of mountain building in a subduction-subduction-transform fault triple junction. Pure Appl. Geophys. 2004, 161, 489-519. [CrossRef]

46. Boyden, J.A.; Müller, R.D.; Gurnis, M.; Torsvik, T.H.; Clark, J.A.; Turner, M.; Ivey-Law, H.; Watson, R.J.; Cannon, J.S. Next-generation plate-tectonic reconstructions using GPlates. In Geoinformatics: Cyberinfrastructure for the Solid Earth Sciences; Randy Keller, G., Baru, C., Eds.; Cambridge University Press: Cambridge, UK, 2011; pp. 95-113.

47. van Hinsbergen, D.J.J.; Vissers, R.L.M.; Spakman, W. Origin and consequences of western Mediterranean sub- duction, rollback, and slab segmentation. Tectonics 2014, 33, 393-419. [CrossRef]

48. Brune, S.; Williams, S.E.; Butterworth, N.P.; Müller, R.D. Abrupt plate accelerations shape rifted continental margins. Nature 2016, 536, 201-204. [CrossRef] [PubMed] 
49. Scotese, C.R.; Schettino, A. Late Permian-Early Jurassic paleogeography of Western Tethys and the World. In Permo-Triassic Salt Provinces of Europe, North Africa and the Atlantic Margins; Soto, J.I., Flinch, J., Tari, G., Eds.; Elsevier: Amsterdam, The Netherlands, 2017; p. 632.

50. Müller, R.D.; Zhirovic, S.; Williams, S.E.; Cannon, J.; Seton, M.; Bower, D.J.; Tetley, M.G.; Heine, C.; Le Breton, E.; Liu, S.; et al. A Global Plate Model including lithospheric deformation along major rifts and orogens since the Triassic. Tectonics 2018, 38, 1884-1907. [CrossRef]

51. Brune, S. Earth's Major Post-Pangea Rift Systems. 2018. Available online: http://portal.gplates.org/cesium/ ?view=rift_v (accessed on 12 September 2020).

52. Paleogeography (750 Ma-Present-Day). Available online: https://www.youtube.com/watch?v= tObhGzHH2aw\&ab_channel=ChristopherScotese (accessed on 12 September 2020).

53. van Hinsbergen, D.J.J. Mediterranean Paleogeographic Reconstructions. 2018. Available online: http: //www.geologist.nl/reconstructions/ (accessed on 12 September 2020).

54. Carminati, E.; Doglioni, C. Alps vs. Apennines: The paradigm of a tectonically asymmetric Earth. Earth-Sci. Rev. 2012, 112, 67-96. [CrossRef]

55. Carminati, E.; Lustrino, M.; Doglioni, C. Geodynamic evolution of the central and western Mediterranean: Tectonics vs igneous petrology constraints. Tectonophysics 2012, 579, 173-192. [CrossRef]

56. Savelli, C. Fast episodes of West-Mediterranean-Tyrrhenian oceanic opening and revisited relations with tectonic setting. Sci. Rep. 2015, 5, 1-11. [CrossRef]

57. Mattioli, M.; Lustrino, M.; Ronca, S.; Bianchini, G. Alpine subduction imprint in Apennine volcaniclastic rocks. Geochemical-petrographic constraints and geodynamic implications from Early Oligocene Aveto-Petrignacola Formation (N Italy). Lithos 2012, 134, 201-220. [CrossRef]

58. Doglioni, C. Main differences between thrust belts. Terra Nova 1992, 4, 152-164. [CrossRef]

59. Lonergan, L.; White, N. Origin of the Betic-Rif mountain belt. Tectonic 1997, 16, 504-522. [CrossRef]

60. Brun, J.P.; Faccenna, C. Exhumation of high-pressure rocks driven by slab rollback. Earth Planet. Sci. Lett. 2008, 272, 1-7. [CrossRef]

61. Vergés, J.; Fernández, M. Tethys-Atlantic interaction along the Iberia-Africa plate boundary: The Betic-Rif orogenic system. Tectonophysics 2012, 579, 144-172. [CrossRef]

62. Bezada, M.J.; Humphreys, E.D.; Toomey, D.R.; Harnafi, M.; Dávila, J.M.; Gallart, J. Evidence for slab rollback in westernmost Mediterranean from improved upper mantle imaging. Earth Planet. Sci. Lett. 2013, 368, 51-60.

63. Calvert, A.; Sandovol, E.; Seber, D.; Barazangi, M.; Roecker, S.; Mourabit, T.; Vidal, F.; Alguacil, G.; Jabour, N. Geodynamic evolution of the lithosphere and upper mantle beneath the Alboran region of the western Mediterranean: Constraints from travel time tomography. J. Geophys. Res. 2000, 105, 10871-10898. [CrossRef]

64. de Lis Mancilla, F.; Stich, D.; Berrocoso, M.; Martín, R.; Morales, J.; Fernandez-Ros, A.; Páez, R.; Pérez-Peña, A. Delamination in the Betic Range: Deep structure, seismicity, and GPS motion. Geology 2013, 41, 307-310. [CrossRef]

65. Vissers, R.L.M. Extension in a convergent tectonic setting: A lithospheric view on the Alboran system of SW Europe. Geol. Belg. 2012, 15, 53-72.

66. Williams, J.R.; Platt, J.P. A new structural and kinematic framework for the Alborán domain (Betic-Rif arc, western Mediterranean orogenic system). J. Geol. Soc. 2018, 175, 465-496. [CrossRef]

67. Platt, J.P.; Vissers, R.L.M. Extensional collapse of thickened continental lithosphere: A working hypothesis for the Alboran Sea and Gibraltar arc. Geology 1989, 17, 540-543. [CrossRef]

68. Viti, M.; Mantovani, E.; Babbucci, D.; Tamburelli, C. Generation of trench-arc-back arc systems in the Western Mediterranean Region driven by plate convergence. Ital. J. Geosci. 2009, 128, 89-106.

69. Belayouni, H.; Brunelli, D.; Clocchiati, R.; Di Staso, A.; El Amrani El Hassani, I.; Guerrera, F.; Kassaa, S.; Laridhiouazaa, N.; Martín-Martín, M.; Serrano, F.; et al. La Galite Archipelago (Tunisia, North Africa): Stratigraphic and petrographic revision and insights for geodynamic evolution of the Maghrebian Chain. J. Afr. Earth Sci. 2010, 56, 15-28. [CrossRef]

70. Zeck, H.P. Betic-Rif orogeny: Subduction of Mesozoic Tethys lithosphere under eastward drifting Iberia, slab detachment shortly before $22 \mathrm{Ma}$, and subsequent uplift and extensional tectonics. Tectonophysics 1996, 254, 1-16. [CrossRef]

71. Lowrie, W.; Heller, F. Magnetic properties of marine limestones. Rev. Geophys. Space Phys. 1982, 20, 171-192. [CrossRef] 
72. Lowrie, L.; Alvarez, W. Paleomagnetic evidence for rotation of the Italian Peninsula. J. Geophys. Res. 1994, 80, 1579-1592. [CrossRef]

73. Scheepersa, P.J.J.; Langereisa, C.G.; Zijdervelda, J.D.A.; Hilgenb, F.J. Paleomagnetic evidence for a Pleistocene clockwise rotation of the Calabro-Peloritan block (southern Italy). Tectonophysics 1994, 230, 19-48. [CrossRef]

74. Durand, B.; Jolivet, L.; Horvath, F.; Séranne, M. The Mediterranean Basins: Tertiary Extension within the Alpine Orogen; Geological Society of London: London, UK, 1999; p. 570.

75. Jolivet, L.; Faccenna, C. Mediterranean extension and the Africa-Eurasia collision. Tectonic 2000, 19, 1095-1106. [CrossRef]

76. Vitale, S.; Amore, O.F.; Ciarcia, S.; Fedele, L.; Grifa, C.; Prinzi, E.P.; Tavani, S.; Tramparulo, F.D.A. Structural, stratigraphic and petrological clues for a Cretaceous-Paleogene abortive rift in the southern Adria domain (Southern Apennines, Italy). Geol. J. 2018, 53, 660-681. [CrossRef]

77. Amadori, M.L.; Belayouni, H.; Guerrera, F.; Martín-Martín, M.; Martin-Rojas, I.; Miclăuş, C.; Raffaelli, G. New data on the Vrancea Nappe (Moldavidian Basin, Outer Carpathian Domain, Romania): Paleogeographic and geodynamic reconstructions. Int. J. Earth Sci. 2012, 101, 1599-1623. [CrossRef]

78. Guerrera, F.; Martín-Martín, M.; Martin-Rojas, I.; Miclăuş, C.; Serrano, F.; Martín-Pérez, J.A. Tectonic control on the sedimentary record of the central Moldavidian Basin (Eastern Carpathians, Romania). Geol. Carpathica 2012, 63, 463-479.

79. Benzeggagh, M.; Abdelkhader Mokhtari, A.; Philippe Rossi, P.; Michard, A.; Abdelkhader El Maz, A.; Chalouan, A.; Saddiqi, O.; Rjimati, E.C. Oceanic units in the core of the External Rif (Morocco): Intramargin hiatus or South-Tethyan remnants? J. Geodyn. 2014, 77, 4-21. [CrossRef]

80. Fernandez, L.; Bosch, D.; Bruguier, O.; Hammor, D.; Caby, R.; Arnaud, N.; Monié, P.; Abdallah, N.; Verdoux, P.; Ouabadi, A.; et al. Vestiges of a fore-arc oceanic crust in the Western Mediterranean: Geochemical constraints from North-East Algeria. Lithos 2020, 370, 105649. [CrossRef]

81. Gimeno-Vives, O.; Frizon de Lamotte, D.; Leprêtre, R.; Haissen, F.; Atouabat, A.; Mohn, G. The structure of the Central-Eastern External Rif (Morocco); Poly-phased deformation and role of the under-thrusting of the North-West African paleo-margin. Earth-Sci. Rev. 2020, 205, 103198. [CrossRef]

82. Michard, A.; Mokhtari, A.; Chalouan, A.; Saddiqi, O.; Rossi, P.; Rjimati, E.C. New ophiolite slivers in the External Rif belt, and tentative restoration of a dual Tethyan suture in the western Maghrebides. Bull. Soc. Geol. Fr. 2014, 185, 313-328. [CrossRef] 